\title{
The Impact of Market Orientation to SMEs Performance with Mediation of Creation Value
}

\author{
ERI NOVARI \\ Universitas Islam Negeri Sunan Gunung Djati Bandung, Jawa Barat, Indonesia \\ Correspondence author: erinovari@uinsgd.ac.id
}

\begin{abstract}
SMEs or Small Medium Enterprises are businesses that keep growing in Indonesia. The resilience of SMEs to economic shock makes a lot of people choose this type of business. This study aims to review the correlation between market orientation, value creation and entrepreneur's commitment to improving SMEs performance. The study conducted through a mediation model of value creation and commitment as the power of the entrepreneur. Respondents of this study are 133 entrepreneurs of creative industry SMEs in Bandung City. Data collection is carried out through questionnaires and processed by path analysis using Lisrel software. The research findings show that market orientation correlates with the improvement of SMEs performance directly and through the mediation of value creation. It is different from entrepreneurs' commitment that cannot mediate the correlation to SMEs performance. The research results strengthen the control of market orientation on the improvement of SMEs performance with support of value creation.
\end{abstract}

Keywords: Market Orientation, Creation Value, Commitment.

\section{Introduction}

SMEs in Indonesia continues to grow; it is due to the government's support and the desire to have a business that continues to increase (Indris \& Primiana, 2015). Actually, SMEs are good to continue to be developed in this country, since SMEs have beneficial characteristics which are more resilient to economic shocks than large companies (Hasibuan, 2015). It explains the importance of evaluating SMEs performance and reviewing factors that can control SMEs performance.

Entrepreneurs in conducting the operations of SMEs certainly use different business strategies (Husso \& Nybakk, 2010), and one that usually used is the market orientation (Gallardo-Vázquez \& Isabel Sánchez-Hernández, 2014). The previous studies have explained that the implementation of market orientation provided a great opportunity for marketing performance and SMEs performance (Nasution et al., 2011). It is because market orientation collaborates all of the elements needed by an entrepreneur, including to be brave to take risks in business, continuing to innovate, and to be proactive towards every change (Urban \& Mothusiwa, 2014).

Business strategies of entrepreneurs certainly need to be supported by novelty, which is contained in the innovation value being created (Kreiser et al., 2013). Hence, an entrepreneur is often required to provide innovation from every decision submitted since innovation is actually closely related to excellence in competition and SMEs performance (Saunila et al., 2014). The level of innovation is an inseparable part in market orientation (Sutapa et al., 2017), so that in controlling market orientation, entrepreneur is aware of the obligation to innovate. Besides that, entrepreneurs are now aware that business competition is not only with similar companies alone (Nasution et al., 2011), but also with other companies of different types and products. That is why entrepreneurs should always be proactive to

Received: 2020-04-29, Revised: 2020-08-19, Accepted: 2020-12-18

Print ISSN: 0215-8175; Online ISSN: 2303-2499. DOI:https://doi.org/10.29313/mimbar.v36i2.5987

Accredited Sinta 2 based on the decree No.10/E/KPT/2019 until 2024. Indexed by DOAJ, Sinta, Garuda, Crossreff, Dimensions 
know every movement conducted by other companies (Gnizy et al., 2014) in order to find out their implementation of internal strategy and marketing performance.

The previous research explains the importance of implementing market orientation related to SMEs performance (Palalic \& Busatlic, 2015). Thus, it is assumed that market orientation controls the achievement of SMEs performance. However, as an entrepreneur, it is should be realized that the SMEs performance also related to many things, including internal factors, such as commitment (Devigne et al., 2016) because it is known that the performance of an industry depends on entrepreneurs' commitment (Javalgi \& Todd, 2011).

Commitment is entrepreneur's behavior that is often constantly controlled (Qi et al., 2014). It is because when an entrepreneur is not aligned with the company's vision and mission, commitment will decrease and threaten company's performance. Entrepreneurs' commitment is susceptible to be distracted considering there are many things that an entrepreneur needs to think about for his/her business (Iraldo et al., 2010). Particularly for SMEs, many entrepreneurs with family businesses are reluctant to run their business seriously and even change their business to another (Cuadrado-Ballesteros et al., 2015), which certainly disrupts the company performance they have started (Ciasullo \& Troisi, 2013). Hence, it can be said that entrepreneurs' commitment is important to achieve SMEs performance.

Many entrepreneurs get their business from their parents/families, not because they built it themselves (Ciasullo \& Troisi, 2013). On the other hand, it also appears that there are entrepreneurs who start a business because they imitate it from a successful business assuming they will achieve the same success (Bergamaschi \& Randerson, 2016). However, family business and imitating other business is not a guarantee for the success of a business. Whatever the origin of a business is, if it is not supported by entrepreneur's commitment, there will be no progress in business (Segaro et al., 2014). Entrepreneurs can be successful not because of other people or companies, but because of the level of commitment they have. As it is explained in previous studies, entrepreneurs' commitment is needed to achieve SMEs performance (Haroon Hafeez et al., 2012).
SMEs in Indonesia continues to increase, both for the new and old ones that start it back again (Wahyudi \& Sani, 2014), meaning there are many offers of products or services from SMEs to customers. Entrepreneurs are required to give more value to products they offer with the assumption they are able to compete with various new kinds of products from competitors (Hasibuan, 2015). The study from previous research has revealed that SMEs have a close relationship with the value of innovation contained in the value creation (Lindman, 2013). This strategy is used by entrepreneurs with the main objection to improving SMEs performance. The phenomenon of value creation explains the importance of implementing the value creation strategy related to the efforts to achieve SMEs performance so that companies will remain sustainable.

Based on the study, SMEs performance seems to be related to market orientation (Huarng \& Yu, 2011), entrepreneurs' commitment (Segaro et al., 2014), and strategy of value creation (Sainio et al., 2011). However, it is well known that commitment is an internal factor of entrepreneurs which is able to be controlled by market orientation (Marshall, 2010). It is similar with the strategy of value creation where it can be controlled by market orientation (Landroguez et al., 2011). By reviewing this phenomenon of market orientation, in relation to SMEs performance, this study focuses on controlling market orientation in improving SMEs performance with the support of mediation from entrepreneurs' commitment and the implementation of value creation. This research is conducted to evaluate SMEs performance of entrepreneurs through controlling market orientation.

Market orientation is a business strategy used in SMEs to understand the company's main target that is customers (Zhou et al., 2009). Getting the knowledge of market orientation means a company has understood the character of its target market and it is able to offer products/services in accordance with customer's intentions (McNaughton et al., 2002). However, the implementation of market orientation is not easy; entrepreneurs need more effort by collaborating all elements in market orientation (K. H. Chen et al., 2016). In SMEs, elements often used are adaptations, risk-taking, innovation, proactive, aggressive and independent (Gnizy et al., 2014).

Market orientation is applied by 
companies with the ultimate goal to achieve SMEs performance (Urban \& Mothusiwa, 2014). In line with previous studies, SMEs performance is the goal of every company and it can be controlled by managing market orientation (Palalic \& Busatlic, 2015). Companies currently use market orientation strategies to achieve SMEs performance (Lonial \& Raju, 2001), which is also correlated with company's service. This opinion can be interpreted as the importance of market orientation as a source of strategy in meeting the company's goals by providing the best service to target market. As it is stated in previous studies, market orientation has a positive impact on SMEs internal behavior, namely entrepreneur's commitment (Lonial \& Raju, 2001), and has a big role in creating value creation (McNaughton et al., 2002). The point of previous study explained that many positive impacts are arising from the implementation of market orientation for SMEs, but the final goal to achieve still remain the SMEs performance. Regarding the phenomenon, hypotheses are built and explained as follows.

Hypothesis 1. Market orientation has a correlation to value creation.

Hypothesis 2. Market orientation has a correlation to commitment entrepreneurs.

Hypothesis 3. Market orientation has a correlation to SME's performance.

Value creation is part of business strategy used by SMEs; the main activity of value creation is related to customers (Awa, 2010). The value creation applied by SMEs is marked by the changes in products and services which are in line with customers' expectations (Ciasullo \& Troisi, 2013). Once again, value creation correlates with the achievement of SMEs performance, as it is stated in the previous research that companies implement the value creation intending to understand customer's expectations to achieve SMEs performance (Ngugi et al., 2010). It means that value creation has an impact on increasing SMEs performance. In values creation, there are assessments used as strategies by entrepreneurs, including customer benefits, business domains, and business networks (Kotler \& Keller, 2012). From the measurement of value creation, there is one goal to achieve that is focusing on customers. Regarding the phenomenon, the next hypotheses are built and can be explained as follows:

Hypothesis 4. Value creation has correlation to SMEs performance.
Entrepreneurs' commitment provides the opportunities for achieving SMEs performance, because the willingness of entrepreneurs to maintain the company (Gadenne et al., 2009). In commitment, there is an effort to help company achieve its goal (Andjarsari et al., 2013). Commitment is often said to be a strong belief and it accepts the company's goals and values. Every entrepreneur must commit himself, but they also need to improve in order to provide optimal results for company development (Baregheh et al., 2012). The theory of business strategy explains the importance of controlling commitment from entrepreneurs to support the achievement of SMEs performance. Commitment is an intangible asset that needs to be maintained by entrepreneurs since it has a long-term orientation in company, and it is able to support company' s goals (Y. S. Chen \& Chang, 2013). Regarding the phenomenon, the next hypotheses are built and can be explained as follows:

Hypothesis 5. Entrepreneurs' commitment has a correlation to SME's performance.

Reviewing the SMEs performance and its relation to other variables, the research hypotheses were built as an objective of this study. Previously, it is stated that SMEs performance is controlled by market orientation (Urban \& Mothusiwa, 2014). In addition, SMEs performance has also been known to be influenced by the implementation of a value creation strategy and entrepreneurs' commitment (Lee et al., 2012; Ngugi et al., 2010). However, it is also known that market orientation is able to control value creation and the commitment strategies of entrepreneurs (Awa, 2010; Maden et al., 2012).

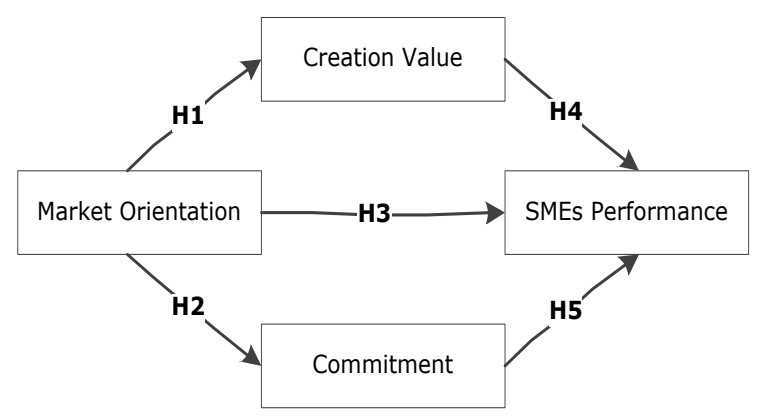

Source: Collaborate (Urban \& Mothusiwa, 2014; Lee et al., 2012; Ngugi et al., 2010; Awa, 2010; Maden et al., 2012)

Figure 1. Hypothesis Model

The point of the previous study explains 
the flow in this research as the focus of research, which is to examine the impact of market orientation on SMEs performance through mediation support from values creation and entrepreneurs' commitment. Furthermore, a hypothetical model will be tested as shown in figure 1.

\section{Research Methodology}

\section{Variables and Methods}

Variables studied in this research were limited to market orientation, value creation, commitment, and SMEs performance. Whereas, the final goal of this study was to evaluate SMEs performance in the implementation of market orientation strategies with the support from the value creation and entrepreneur's commitment. Considering the research objectives, this study used a survey method conducted to SMEs of creative industries in Bandung as the city with big number of SMEs in Indonesia. 133 respondents for this research were selected through random sampling technique. The respondents are an entrepreneur in SMEs in creative industry who are consistent to operate the organization at least five years and focus on the product offering to measure the commitment of business. Respondents were selected for this research since this study was included as the experimental research to study the research model through a portion of the population.

\section{Instruments of Research}

Data from entrepreneurs were collected through questionnaires with predefined answers to easily collect data according to research instruments. The answer was determined by Likert scale approach which was namely the value of " 1 " for "Strongly disagree" criteria and the value of " 5 " for "Strongly agree" criteria. The research instruments were determined based on the previous survey literature. Market orientation used five measurements: risktaking, innovation, proactive, aggressive, and independent (Gnizy et al., 2014). In value creation, three measurements were used, namely customer benefit, business domain, and business network (Tsai et al., 2012). The measurements for commitment from entrepreneurs used were affective, continue, and normative (Ma'amor et al., 2016). Whereas, SMEs performance was assessed by measuring profitability, benefits, and market share (Sidiqqoh \& Alamsyah,
2017). The measurement was used to assess entrepreneurs' opinions to research variables.

Data from the questionnaire then processed through path analysis approach; it considered that there was mediation variable in the hypothesis model (figure 1). The analysis tool used is Lisrel so that the research result can be said as a goodnessof-fit model. At the end of research, the five research hypothesis tests are conducted to emphasize the research results.

\section{Results and Discussions}

The study results are mainly sourced from 133 respondents of entrepreneurs who provide data to be processed. The entrepreneurs are from SMEs of creative industries in Bandung City, West Java province. The selected entrepreneurs are those who have been doing business for at least 5 years, meaning they commit to running a business. It relates to the goal of research in measuring the achievement of SME's performance.

Most SMEs are owned by maleentrepreneurs, which are about $87 \%$. Their business are mostly food, such as restaurants amount to $46 \%$, followed by fashion business as much as $24 \%$, and the rest are varied from retail business to souvenirs. Entrepreneurs mostly set up business of their passion that is not a family business, which seems clear that they have the desire for entrepreneurship. But unfortunately, most entrepreneurs are migrants from outside Bandung. They come to Bandung with great hope to do business because the opportunity in big city is greater than in their respective regions. The research model test is conducted to respondents' data through hypothesis test using Lisrel analysis tools. The results of subsequent studies regarding the value of relationship between variables of research model are presented in figure 2 .

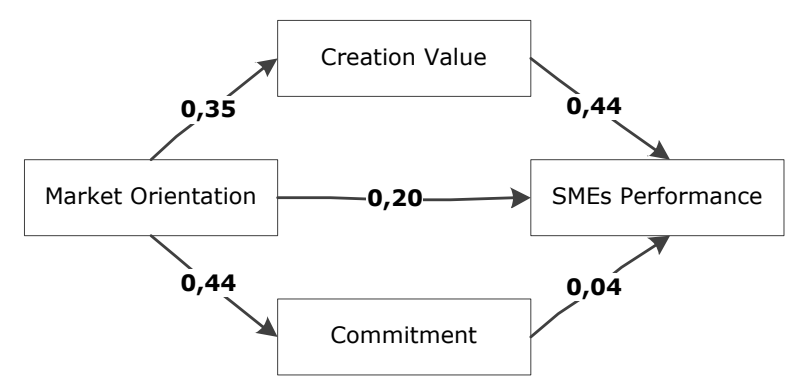

Figure 2. Result of Research Model

Based on the results presented in figure 2 , all variables have a positive relationship. 
Market orientation has a positive correlation to both SMEs performance directly and through value creation and commitment. Similarly, value creation has a good correlation to SMEs performance directly, but it seems inversely proportional to entrepreneurs' commitment which seems unable to support directly to the improvement of SMEs performance. Before explaining the research findings, the test results of research instruments and the fittest of research model are presented firstly, which are shown in table 1 and table 2 . In table 1 regarding the results of research instrument test, it is known that all instruments are valid and reliable based on data values from Pearson correlation above 0.5, Cronbach's Alpha value above 0.7, and Loading Factor value above 0.5. Based on these results, the research instruments can be used to explain the research model. The next most important test result is the fittest of research model described in table 2 . Based on the research results, it is explained that the criteria value of degree of freedom, chisquare and $p$-value require the criteria (cut of value). It seems clear that research model of SMEs performance is influenced by market orientation and it is mediated by the values creation and commitment stated to be fit of model.

Table 1

Validity and Reliability Test

\begin{tabular}{lllll}
\hline Variables & Instruments & $\begin{array}{l}\text { Pearson } \\
\text { Correlation }\end{array}$ & $\begin{array}{l}\text { Cronbach's } \\
\text { Alpha }\end{array}$ & $\begin{array}{l}\text { Loading } \\
\text { Factors }\end{array}$ \\
\hline Market Orientation & Taking Risk & 0,779 & 0,704 & 0,561 \\
& Innovation & 0,626 & & 0,627 \\
& Proactive & 0,563 & & 0,703 \\
& Aggressive & 0,616 & & 0,761 \\
& Independent & 0,693 & 0,598 \\
\hline Value Creation & Customer Benefit & 0,731 & 0,764 & 0,692 \\
& Business Domain & 0,756 & 0,736 & 0,715 \\
\hline Commitment & Business Network & 0,693 & & 0,833 \\
& Affective & 0,863 & 0,841 \\
& Continue & 0,854 & 0,751 \\
\hline SMEs Performance & Normative & 0,792 & 0,850 \\
& Profitability & 0,874 & 0,973 \\
& Benefit & 0,896 & 0,972 \\
\hline
\end{tabular}

Source: Collaboration of Studies (Gnizy et al., 2014; Tsai et al., 2012; Ma'amor et al., 2016; Sidiqqoh \& Alamsyah, 2017)

Table 2

Goodness of Fit Test

\begin{tabular}{llll}
\hline Goodness of Fit Criteria & $\begin{array}{l}\text { Cut of } \\
\text { Value }\end{array}$ & Result & Goodness of Fit \\
\hline Degrees of Freedom & $\leq 1.00$ & 0 & Fit \\
\hline Chi-Square & $\leq 1.00$ & 0.0 & Fit \\
\hline P-Value & $>0.05$ & 1.00 & Fit \\
\hline
\end{tabular}

Source: Hair et al., 2011

Table 3

Hypothesis Test

\begin{tabular}{llll}
\hline No. & Hypothesis & t-value & Result \\
\hline H1 & Market Orientation to Creation Value & 4,26 & Significant \\
\hline H2 & Market Orientation to Commitment & 5,62 & Significant \\
\hline H3 & Market Orientation to SMEs Performance & 2,38 & Significant \\
\hline H4 & Creation Value to SMEs Performance & 5,64 & Significant \\
\hline H5 & Commitment to SMEs Performance & 0,45 & No \\
\hline
\end{tabular}


The last test results showed there were hypothesis tests presented in table 3 for the summary. Based on the results, it was revealed that all of hypothesis tests were said to be significant, which are hypothesis $1,2,3$, and 5 . However, for the hypothesis 4, entrepreneurs' commitment has no significant impact directly on the increase of SMEs performance. This study results will be discussed in depth in the next part to explain research finding along with research benefits and also recommendations for further research, particularly SMEs.

\section{The Mediation of Value Creation to Market Orientation and Entrepre- neur's Commitment}

Market orientation is a business strategy used by entrepreneurs in SMEs to achieve SMEs performance (Urban \& Mothusiwa, 2014). However, support from other factors is also needed, namely the value creation and entrepreneurs' commitment. The analysis of research results explained that market orientation has a relationship with the implementation of value creation and entrepreneurial commitment, in which they surely can support the main goal of SMEs performance.

The first finding from the results section of this study explains the impact of market orientation on value creation. It can be seen in the correlation value of market orientation to value creation of 0.35 (figure 2), or an impact of $12.2 \%$. This finding is actually in line with previous studies which explain that business strategies in SMEs through empowering market orientation have an impact on corporate value creation (Awa, 2010). This research refines the previous studies and it is aware that value creation can be done by paying attention to market orientation. In value creation, especially SMEs, there are several assessments including customer benefits, business domains, and business networks (table 2). Based on test results in table 1 , all elements in value creation have an impact, which can be seen from Loading Factors for all assessments of instruments that reached above 0.6. Assuming that in creating value creation for SMEs, it is necessary to prioritize the sequence of strategies starting from business domain, business network, and finally customer benefit. Implementing strategies in value creation certainly generates an impact of value creation on other variables, such as achieving SMEs performance.
On the other hand, it is stated that market orientation also had an impact on entrepreneur's commitment, which can be seen from correlation value of market orientation to commitment of 0.44 (figure 2), or an impact of $19.3 \%$. This result is greater than the impact of market orientation on value creation. It is assumed because the assessment instruments of market orientation have a closeness with the characteristics of entrepreneurs. The measurements used in market orientation include risk-taking, innovation, proactive, aggressive, and independent (table 2) which largely in line with the spirit of entrepreneurship in deciding for SMEs. Although the impact of market orientation on value creation and commitment does not differ so much, this is recommended in the strategy implementation. It is necessary to prioritize market orientation, given its impact on the implementation of value creation and commitment behavior of entrepreneurs.

The study result was confirmed by the research hypothesis test (table 3 ), whereby it is stressed that market orientation has a significant relationship with value creation (H1) and it also has a significant relationship with entrepreneurs' commitment (H2). This finding provides a great opportunity for SMEs because collaboration from entrepreneurs through market orientation has an impact on company's strategy of creating value and impacting on the entrepreneur behavior, namely commitment they have. Surely, the expected result is its ability to support SMEs performance.

\section{Mediation of Creation Value for SMEs Performance}

This study carried out a mediation test of value creation and entrepreneur's commitment to find out the support of these two variables for the achievement of SMEs performance. Based on the study results, it is found that value creation has a relationship with SMEs performance; it is shown by the correlation value of 0.44 (table 2 ). It means that SMEs performance can be controlled directly by value creation. On the other hand, it is known that entrepreneurs' commitment has a relationship with SMEs performance. However, when it is examined deeper, the relationship is very weak and it does not have a good impact on the improvement of SMEs performance; this is in line with the value commitment of SMEs performance that gained a very weak result of 0.04 (table 2 ). This 
finding explains that in measuring the success of SMEs performance, it is necessary to prioritize the implementation of value creation strategy and not entrepreneurs' commitment since it does not have a direct impact on the performance. The support of value creation in SMEs performance is in line with previous research which explains that value creation has a positive impact on improving SMEs performance (Ciasullo \& Troisi, 2013).

The interesting thing in this part of research is the support of mediation of value creation. It is known that market orientation has an impact on value creation (figure 2), and on the other hand, value creation directly has an impact on SMEs performance. It means that value creation can mediate the relationship of market orientation with the increasing of SMEs performance. Part of this research is made clearly through the research hypothesis test presented in table 3 , where value creation has a significant relationship with achieving SMEs performance $(\mathrm{H} 4)$, and entrepreneur's commitment does not have a significant relationship with SMEs performance (H5). These results become recommendations in subsequent studies in controlling SMEs performance through business strategies, such as mediation of value creation.

\section{Driver of Market Orientation for SMEs Performance}

The recent of research finding is a study of market orientation impact on SMEs performance directly. The main objective of this research is to examine the control over market orientation. Based on study results, it is found that market orientation has a positive relationship directly with SMEs performance with a correlation value of 0.20 (Figure 2 ). The results are explained by hypothesis testing in table 3, stating that the relationship of market orientation with SMEs performance is significant $(\mathrm{H} 3)$, or it has a significant impact. The results presented are in line with the previous research, especially for SMEs, stating that market orientation is a business strategy often controlled by entrepreneurs in achieving SMEs performance (Urban \& Mothusiwa, 2014). More precisely, the research finding refines previous research and it certainly has benefits for SMEs in understanding SMEs business strategies.

Figure 2 also shows that market orientation is able to directly control value creation and entrepreneurs' commitment. It means research findings clarify the position of market orientation that has an ability to control SMEs performance both directly and through mediation of value creation and entrepreneurs' commitment. Based on the research findings, a model that can support the achievement of SMEs performance is a market orientation that control SMEs performance through the support of value creation. This model does not include entrepreneurs' commitment because it cannot change direction to SMEs performance.

This study has important information, especially relating to the implementation of business strategies through market orientation. It is expected to be able to support SMEs in company operations, so that they can be developed towards SMEs performance.

\section{Conclusions}

The research focuses on examining the correlation of market orientation, value creation and commitment from entrepreneurs in supporting the improvement of SMEs performance. Market orientation is a strategy that is often used by entrepreneurs; it is related to the efforts to achieve SMEs performance. However, it needs to be supported by other factors because it does not have significant impact directly. Based on the study results, it is found that the strategy of value creation and entrepreneurs' commitment have a good correlation to market orientation and SMEs performance; but in improving SMEs performance, it only needs mediation of value creation. Thus, it is emphasizing the meaning of the strategy implementation of value creation, which is the right mediation between market orientation and SMEs performance. The findings of this research are certainly useful, especially for SMEs, where it needs to control SMEs performance through market orientation with the support of value creation implementation. Things that need to know relating to market orientation is control for taking risk, innovation, proactive, aggressive, and independent, where all these behaviors are very suitable for entrepreneurs in SMEs.

Based on the research result, entrepreneur's commitment can be controlled by the implementation of market orientation. A suggestion for further research is that researchers need to study the other impacts of market orientation on entrepreneurial behavior besides the commitment since market orientation plays an important role in supporting entrepreneur performance, as 
well as SMEs performance. In addition, the current research is limited to SMEs for creative industries in Bandung City, so that it can be developed further to a broader object in other city or regions in Indonesia. Many factors can control SMEs performance; it is not limited to the implementation of market orientation strategies, so it is suggested to examine the other strategies, such as distinctive capability and distinctive competence which are owned by many entrepreneurs.

\section{References}

Andjarsari, T., Nimran, U., EkoSoetjipto, B., \& Djatmika, E. T. (2013). The Effect of Organizational Learning on Organizational Commitment, Innovation and Job Satisfaction (A Study on SMEs under CSR Program of PT Telkom Regional V, East Java, Indonesia). Interdisciplinary Journal of Contemporary Research In Business, 5(2), 455-465.

Awa, H. O. (2010). Democratizing the New Product Development Process: A New Dimension of Value Creation and Marketing Concept. International Business Research, 3(2), 49-60. https://doi.org/10.5539/ibr. v3n2p49

Baregheh, A., Rowley, J., Sambrook, S., \& Davies, D. (2012). Innovation in food sector SMEs. Journal of Small Business and Enterprise Development, 19 (2), 300-321. https://doi . org/10.1108/14626001211223919

Bergamaschi, M., \& Randerson, K. (2016). The futures of family businesses and the development of corporate social responsibility. Futures, 75, 54-65. https:// doi.org/10.1016/j.futures.2015.10.006

Chen, K. H., Wang, C. H., Huang, S. Z., \& Shen, G. C. (2016). Service innovation and new product performance: The influence of market-linking capabilities and market turbulence. International Journal of Production Economics, 172, 54-64. https://doi.org/10.1016/j. ijpe.2015.11.004

Chen, Y. S., \& Chang, C. H. (2013). Enhance environmental commitments and green intangible assets toward green competitive advantages: An analysis of structural equation modeling (SEM). Quality and Quantity, 47(1), 529-543. https://doi. org/10.1007/s11135-011-9535-9

Ciasullo, M. V., \& Troisi, O. (2013). Sustainable value creation in SMEs: A case study. TQM Journal, 25(1), 44-61. https://doi. org/10.1108/17542731311286423

Cuadrado-Ballesteros, B., Rodríguez-Ariza, L., \& García-Sánchez, I. M. (2015). The role of independent directors at family firms in relation to corporate social responsibility disclosures. International Business Review, 24(5), 890-901. https://doi. org/10.1016/j.ibusrev.2015.04.002

Devigne, D., Manigart, S., \& Wright, M. (2016). Escalation of commitment in venture capital decision making: Differentiating between domestic and international investors. Journal of Business Venturing, 31(3), 253-271. https://doi.org/10.1016/j. jbusvent.2016.01.001

Gadenne, D. L., Kennedy, J., \& McKeiver, C. (2009). An empirical study of environmental awareness and practices in SMEs. Journal of Business Ethics, 84(1), 45-63. https://doi.org/10.1007/s10551008-9672-9

Gallardo-Vázquez, D., \& Isabel SánchezHernández, M. (2014). Structural analysis of the strategic orientation to environmental protection in SMEs. $B R Q$ Business Research Quarterly, 17(2), 115-128. https://doi.org/10.1016/j. brq.2013.12.001

Gnizy, I., Baker, W. E., \& Grinstein, A. (2014). Proactive learning culture: A dynamic capability and key success factor for SMEs entering foreign markets. International Marketing Review, 31(5), 477-505. https://doi.org/10.1108/IMR-10-20130246

Hair, J., Celsi, M. W., Money, A. H., Samouel, P., \& Page, M. J. (2011). Essential of Business Research Methods, Second Edition. M.E. Sharpe Inc.

Haroon Hafeez, M., Noor Mohd Shariff, M., \& bin Mad Lazim, H. (2012). Relationship between Entrepreneurial Orientation, Firm Resources, SME Branding and Firm's Performance: Is Innovation the Missing Link? American Journal of Industrial and Business Management, 02(04), 153-159. https://doi.org/10.4236/ ajibm.2012.24020

Hasibuan, S. (2015). SMEs development strategy for competitive and sustainable typical local snacks of Banten Province. International Journal on Advanced Science, Engineering and Information Technology, 5(6), 410-414. https://doi.org/10.18517/ ijaseit.5.6.602

Huarng, K. H., \& Yu, T. H. K. (2011). Entrepreneurship, process innovation and value creation by a nonprofit SME. Management Decision, 
49(2), 284-296. https://doi. org/10.1108/00251741111109160

Husso, M., \& Nybakk, E. (2010). Importance of internal and external factors when adapting to environmental changes in SME sawmills in Norway and Finland: The managerâ $\epsilon^{\mathrm{TM}} \mathrm{s}$ view. Journal of Forest Products Business Research, 7(1), 14. http://www.forestprod.org/buy publications/journal_of_forest_products_ business_research.php

Indris, S., \& Primiana, I. (2015). Internal And External Environment Analysis On The Performance Of Small And Medium Industries SMEs In Indonesia. International Journal of Scientific \& Technology Research, 4(4), 188-196.

Iraldo, F., Testa, F., \& Frey, M. (2010). Environmental Management System and SMEs: EU Experience, Barriers and Perspectives. In Environmental Management (Issue September). https:// doi.org/10.5772/10098

Javalgi, R. G., \& Todd, P. R. (2011). Entrepreneurial orientation, management commitment, and human capital: The internationalization of SMEs in India. Journal of Business Research, 64(9), 1004-1010. https://doi.org/10.1016/j. jbusres.2010.11.024

Kotler, P., \& Keller, K. L. (2012). Marketing Management. Prentice-Hall.

Kreiser, P. M., Marino, L. D., Kuratko, D. F., \& Weaver, K. M. (2013). Disaggregating entrepreneurial orientation: The non-linear impact of innovativeness, proactiveness and risk-taking on SME performance. Small Business Economics, 40(2), 273291. https://doi.org/10.1007/s11187012-9460-x

Landroguez, S. M., Castro, C. B., \& Cepeda-Carrión, G. (2011). Creating dynamic capabilities to increase customer value. Management Decision, 49(7), 1141-1159. https://doi. org/10.1108/00251741111151181

Lee, Y. K., Kim, Y. S., Lee, K. H., \& Li, D. xin. (2012). The impact of CSR on relationship quality and relationship outcomes: A perspective of service employees. International Journal of Hospitality Management, 31(3), 745-756. https:// doi.org/10.1016/j.ijhm.2011.09.011

Lindman, M. (2013). How do SMEs bond to their retailers through value creation? Journal of Small Business and Entrepreneurship, 26(5), 537-552. https://doi.org/10.1080 /08276331.2013.876766

Lonial, S. C., \& Raju, P. S. (2001). The
Impact of Environmental Uncertainty on the Market Orientation - Performance Relationship: A Study of the Hospital. 3(1), 5-27.

Ma'amor, H., Achim, N., Yunus, N. S. N. M., Hashim, N., \& Haque, A. (2016). The Influence of Personality Traits Towards Quality Pledge. Procedia Economics and Finance, 37(16), 73-79. https://doi. org/10.1016/s2212-5671(16)30095-8

Maden, C., Arıkan, E., Telci, E. E., \& Kantur, D. (2012). Linking Corporate Social Responsibility to Corporate Reputation: A Study on Understanding Behavioral Consequences. Procedia - Social and Behavioral Sciences, 58, 655-664. https:// doi.org/10.1016/j.sbspro.2012.09.1043

Marshall, N. W. (2010). Commitment, Loyalty And Customer Lifetime Value: Investigating The Relationships Among Key Determinants. Journal of Business \& Economics Research (JBER), 8(8). https:// doi.org/10.19030/jber.v8i8.753

McNaughton, R. B., Osborne, P., \& Imrie, B. C. (2002). Market $\square$ oriented value creation in service firms. European Journal of Marketing, 36(9/10), 990-1002. https:// doi.org/10.1108/03090560210437299

Nasution, H. N., Mavondo, F. T., Jekanyika, M., \& Oly, N. (2011). Industrial Marketing Management Entrepreneurship : Its relationship with market orientation and learning orientation and as antecedents to innovation and customer value. Industrial Marketing Management, 40(3), 336-345. https://doi.org/10.1016/j. indmarman.2010.08.002

Ngugi, I. K., Johnsen, R. E., \& Erdélyi, P. (2010). Relational capabilities for value co-creation and innovation in SMEs. Journal of Small Business and Enterprise Development, 17(2), 260-278. https:// doi.org/10.1108/14626001011041256

Palalic, R., \& Busatlic, S. (2015). Exploratory Research on Relationship between Entrepreneurial Orientation Dimensions and Business Performance and Growth of Fast and Slow Growing Small and Medium Enterprises in Bosnia and Herzegovina. International Journal of Business and Management, 10(2), 15-31. https://doi. org/10.5539/ijbm.v10n2p15

Qi, J. Y., Qu, Q. X., \& Zhou, Y. P. (2014). How does customer self-construal moderate CRM value creation chain? Electronic Commerce Research and Applications, 13(5), 295-304. https://doi. org/10.1016/j.elerap.2014.06.003

Sainio, L. M., Saarenketo, S., Nummela, N., 
\& Eriksson, T. (2011). Value creation of an internationalizing entrepreneurial firm: The business model perspective. Journal of Small Business and Enterprise Development, 18(3), 556-570. https:// doi.org/10.1108/14626001111155709

Saunila, M., Pekkola, S., \& Ukko, J. (2014). The relationship between innovation capability and performance: The moderating effect of measurement. International Journal of Productivity and Performance Management, 63(2), 234-249. https:// doi.org/10.1108/IJPPM-04-2013-0065

Segaro, E. L., Larimo, J., \& Jones, M. V. (2014). Internationalization of family small and medium sized enterprises: The role of stewardship orientation, family commitment culture and top management team. International Business Review, 23(2), 381-395. https://doi. org/10.1016/j.ibusrev.2013.06.004

Sidiqqoh, S. A., \& Alamsyah, D. P. (2017). Peningkatan Kinerja Bisnis Usaha Mikro Melalui Kajian Komitmen dan Ambisius Pengusaha. Jurnal Ecodemica, 1(2), 250-256.

Sutapa, Mulyana, \& Wasitowati. (2017). The Role of Market Orientation, Creativity and Innovation in Creating Competitive
Advantages and Creative Industry Performance. Jurnal Dinamika Manajemen, 8(2), 152-166. https://doi.org/10.15294/ jdm.v8i2.12756

Tsai, M. T., Chuang, L. M., Chao, S. T., \& Chang, H. P. (2012). The effects assessment of firm environmental strategy and customer environmental conscious on green product development. Environmental Monitoring and Assessment, 184(7), 4435-4447. https://doi.org/10.1007/s10661-0112275-4

Urban, B., \& Mothusiwa, M. (2014). Planning flexibility and entrepreneurial orientation : A focus on SME performance and the influence of environmental perceptions. Management Dynamics, 23(I), 58-73.

Wahyudi, I., \& Sani, G. A. (2014). Interdependence between Islamic capital market and money market: Evidence from Indonesia. Borsa Istanbul Review, 14(1), 32-47. https://doi.org/10.1016/j. bir.2013.11.001

Zhou, K., Brown, J., \& Dev, C. (2009). Market orientation, competitive advantage, and performance: A demand-based perspective. Journal of Business Research, 62(11), 1063-1070. 